\title{
QUESTIONING HETERONORMATIVE HIGHER EDUCATION SPACES: EXPERIENCES OF LESBIAN WOMEN AT A SOUTH AFRICAN UNIVERSITY
}

M. Naidu*

Anthropology

e-mail: naiduu@ukzn.ac.za

\author{
V. Mutumbara* \\ PhD Candidate \\ International Relations \\ *University of KwaZulu-Natal \\ Durban, South Africa
}

\section{ABSTRACT}

This article narrows the gaze on sexual orientation and focuses on a group of university-going women who self-identify as lesbian. The article works from the understanding that there is an intersectional prism through which women's experiences need to be understood. Thus, working within an intersectional paradigm and narrative analysis, the article attempts to situate the experiences and shared stories of a core sample community of a small group of university women against a human rights discourse and what is understood by the women, as their entitlement to full sexual citizenship within the institutional spaces of the university. Findings reveal that the women feel that the imperatives of university transformation hold little meaning in terms of their personal sexual orientation. Findings also show that in the perceived absence of institutional support, the women draw on nodal ties and social capital embedded in student social groups where kinship and acceptance is offered.

Keywords: women, lesbian, sexual citizenship, human rights, body, violence

\section{INTRODUCTION}

Although there is no standard definition of what human rights are, the issue of human rights has cut across the unfolding debate of legalization of homosexuality within many countries in sub-Saharan Africa. The Office of the High Commissioner for Human Rights (OHCHR 1996) asserts that 'Human rights are rights inherent to all human beings, whatever ones nation, ethnic origin, color, religion, language or any other status'. In this (1996) declaration, the any other status appended to the trailing tail end of the sentence, ostensibly covers sexual orientation. Forsythe (2009) offers a somewhat fuller definition of human rights as a, means to a greater 
social end and understands it as a legal system that informs us which rights are considered most fundamental.

However, like many definitions, this definition is itself somewhat slippery and can be discursively reassembled in terms of particular cohered understandings of 'social end' and which and what are construed as one's (most) fundamental rights. In many contexts, it would appear that sexual rights and rights to sexual orientation are perceived as less fundamental than others. This is evocative of George Orwell's classic text, Animal Farm, where Stalinist 'Napoleon the Pig' stretches and twists the subtext of the commandment 'all are equal' into 'all are equal, but some are more equal than others'. Clearly the right to sexual orientation is a 'right' that is perceived by many as a less equal, and a less fundamental human right, and that much less of a central importance as the other (human) rights.

Thus, whilst the promotion of human rights has garnered much attention in the international community, the chasm between human rights and the right to freely enact and experience ones sexual orientation is still glaring when it comes to the lesbian and gay communities. Despite the widespread conversation about human rights, homophobic attitudes often become imbricated with the lack of legal protection for lesbians and gays, further 'allowing' gross violations of human rights.

The status of sexuality politics in international relations has also received much attention in the contemporary world. It has furthermore impacted issues of foreign policy, obliging a relook at the construction of human rights within an International Relations concept (see Thiel 2014). However, in more than 70 countries, legislature makes it a crime to be homosexual. The very vocal and highly publicized instance of Zimbabwean President Robert Mugabe publicly stating that the he believed gays and lesbians were 'lower than pigs and perverts and therefore have no rights [emphasis added]' is a case in point (Tiripano 2000, 6). As we continue with our analogy and the political allegory employed by author George Orwell, we see that even 'pigs' are to be afforded greater respect and rights than 'gays'.

The polemic of lesbian and gay rights in post-independence Africa thus remains controversial, since for most of the states it is deemed and couched in the binary of taboo/immoral, irreligious and inhuman (see Naidu 2013). Post-apartheid South Africa however, embraced within its reconstituted legislature, alternate sexualities and sexual orientation. However, tragically, constitutionality has not guaranteed an end to social discrimination.

In the context of women, Herek and Beril's (1992) assertion all of more than two decades ago that 'lesbian women are part of a marginalized population' that places them at risk of 
targeted victimization across diverse spaces and contexts, has remained unchanged. Higher education spaces appear to be no exception.

Research done within the South African context on lesbian persons shows that homophobia exists in many university communities (see Peters 2003; Mohipp and Morry 2004; Mavhandu-Mudzusi and Netshandama 2013). Research on homosexuality and lesbianism in the Black African religious community (Naidu 2013) also underscores the structural intersectionalities of race and gender entangled within same sex desire and relationships in the context of mainstream Christianity and African cultural mores. Thus, for Black African women who identify as lesbian and who enter the higher education terrain, there are multiple and intersecting indices of discrimination. For it is construed as especially sinful to be lesbian within the multiple contexts of the many African cultural traditions in South Africa. Thus, while there is discrimination of the lesbian community, arguably this discrimination is heightened with the African communities where particular patriarchal masculinities and prerogatives also co-exist (see Naidu and Ngqila 2013).

Mary Hames' $(2007,51)$ utterance eight years ago, is no less true today, that, '[S]exual orientation in the academy remains a site of deep contestation'. Collier's (2001) study within higher educational institutions also revealed that women who self-identified as lesbian are often viewed as the non-normative 'other'. Collier (2001) posits that lesbian students in university communities often avoid 'coming out' or publically disclosing their sexual preference for the sake of protecting their academic careers, in terms of academic longevity and acceptance within smaller postgraduate classes etc.

Longerbeam et al. (2007) however, quite rightly, one contends, points out that research on gay and lesbian students, offers an incomplete picture of their overall university experience. This is borne out by studies such as that of Arndt and De Bruin (2006) and Swank and Raiz (2010) which focused on the attitudes of heterosexual students towards students who selfidentified as lesbian, rather than on lesbian students themselves.

Given the above landscape of previous studies, this particular study thus focuses on the experiences of the Black African lesbian women at the University of KwaZulu-Natal and attempts to show that the women understood their sexual orientation as a fundamental human right.

\section{METHODOLOGICAL AND THEORETICAL FRAMEWORK}

The study was located at the University of KwaZulu-Natal (UKZN) over a seven month period and sampled an initial 15 female students who all self-identified as lesbian. All participants 
were Black African women, although this was not an initial delimitation of the study. The initial inclusion/exclusion criteria, while spelling out criteria of 'women' and 'same sex desire as sexual preferences' did not spell out any particular racial delimitation. However, although students from other race groups were approached, these students declined to participate. One surmises that, given the sensitive nature of the perceived questions, and the interviewer herself being a Black African student, possibly facilitated securing Black African participants.

The later core sample comprised 8 participants. From the initial 15 participants this smaller group of 8 emerged as women who were comfortable with being interviewed several times. The qualitative data analysis was in turn drawn mainly from this smaller core sample. The design took the shape of a qualitative exploratory study and was designed to be cognisant that qualitative research demands sustained and repeated contact and rapport building with participants.

While participants were recruited from across all five campuses of the University, the core participants were based at the Howard College Campus. All interviews were conducted by one of the authors, who as a young Black African female, herself a student at UKZN, was able to broker a relationship with the lesbian students through a key informant (who self-identified as lesbian). The study was however, reflexive of the fact that the researcher's/interviewer's status as heterosexual female could have potentially influenced the participants' (un)willingness to share intimate details of their experiences. To this end, the many weeks of initial rapport and relationship building with the participants assisted in forging trust.

Contact was also initiated with the LGBTI Forum leader at UKZN, who was willing to assist with recruiting participants for the study, although most of the participants were eventually recruited through the key informant and through snowballing. Snowballing as a sampling technique refers to participant referrals. Although snowball sampling has some drawbacks as the participants' identities are known to each other, the technique does provide a feasible recruitment strategy especially within contexts of small or 'invisible' sample communities. According to the LGBTI Forum leader, there are no coloured, white or Indian lesbian students who are members of the Forum. This further steered the final racial demographic of the sampled group.

Many, although not all, of the women finally sampled belonged to the LGBTI Forum. The study thereafter proceeded with Gatekeeper permission from the university registrar and the LGBTI Forum leader and informed consent letters were prepared for the participants. It was made clear that respect and anonymity would be maintained at all times and participants were guaranteed that pseudonyms would be used in the write up. 
In qualitative research, the researcher attempts to study behaviour in a natural setting, using peoples' accounts as data. Interviews thus took the form of unstructured encounters. Harrison $(2001,90)$ defines an interview as an encounter between a researcher and a respondent, where the respondent's answers provide the raw data. An unstructured interview takes the shape of a free flowing conversation relying heavily on the 'quality' of the social interaction between the researcher and the participant. This allows flexibility and ‘discovery’ of meaning.

Each participant was involved in at least three to four interviews. The study was designed to capture the phenomenological experiences of the women. The term phenomenology is used as a descriptor of a qualitative method that focuses on human experience (see Langdridge 2007). Narrative inquiry works on the proposition that we come to understand and give meaning to our lives through 'story'.

The interviews took place on the premises of the University of Kwazulu Natal in one of the venues that LGBTI group meetings were usually held. Details of UKZN student counselling services (with whom contact had been made) were in turn made available to the participants in the event that the interview questions were experienced as traumatic.

Focus groups were also used with groups of three to four participants. This is considered a valuable means of gathering data in a communal context. This approach proved highly useful because it afforded the women space to interact with each other and also to collectively reflect on their experiences on campus, which helped the researchers appreciate and gain insight on dominant perceptions and beliefs that cohered within the group as a whole. The participants for the focus groups were also the same participants interviewed individually.

Interviews were later transcribed. Bertram and Christiansen (2014) state that, 'the first step in data analysis is to reduce and to organize the data so that the researchers can begin to discern the patterns or themes that emerge'. Data from the interviews were then manually and thematically coded. The narrative analyses were made available to the student participants and they were invited to comment on how they felt their experiences had been captured. That vital second tier and layer of feedback was in turn woven into the final write up and served to enrich and offer a deeper nuanced presence of the university women's 'voice' in the study.

\section{FINDINGS: NARRATIVES OF BEING LESBIAN AT UKZN}

While the narratives included a large number of issues, particular issues emerged as reiterative and cohered around three dominant themes. The first two themes are presented as disabling and violently experienced as:

1) Lesbian as being abnormal.

2) Violence of words as verbal harassment. 
The third theme is presented as a form of agency and shared by the women as;

3) Strength in nodal networks of support.

The emergent themes are thus experiences of both disempowerment as well as agency. It must be pointed out however, that research and the act of re-presenting data are always somewhat 'messy' to borrow a researcher term. To expect 'clean', discrete and separate narrative themes would be naïve. For the women's stories and voices show that the narratives and issues often overlap and leech one into the other and are entangled and embedded one into the other. This is especially so with theme one organically overlapping with theme two. It is with this caveat that we turn now to the women's voices.

\section{Theme: Lesbian as being abnormal}

Doris shared that she felt that people on the campus gazed upon her as an abnormal person,

One of the challenges I have faced here on campus is that of people not looking at me as a normal individual and using 'those' words on me.

The discourse of 'normal' and (ab)normality experienced in the context of the corporeality of their bodies and the sexuality inscribed on their bodies, surfaced often in the women's stories, forcing them (they said) to question the value in 'coming out' or disclosing their sexual orientation to the wider student community. Such forced non-disclosure, in turn emerged as a kind of self-imposed erasure.

I was even so afraid to bring my partner to my residence and it took a very long time until she asked why I never asked her to come visit. As much as my friends knew about it, [referring to her sexual orientation] I didn't want the whole residence to just know me as that person. The students here are not accepting of people who are different ... it's like being back at home ...

I didn't want to be 'the lesbian', and I was scared and felt it wasn't normal and I didn't want to be this person who would be discriminated against. Society as whole discriminates us and it's no different on campus ... so I did not want to tell anyone. (Xoliswa).

Xoliswa's story typifies the (often compelled self-imposition of) self-abjection and selfalienation that is experienced by many women who are lesbian students in higher education. Thinking that they may have escaped particular parochial cultural views about their (sexual) difference from their rural or peri-urban birth places and families, their assumptions of meeting greater acceptance at university, suffers rude awakening.

Referring to her African cultural roots, Xoliswa stated that the residence was 'no 
different'. It bears noting that the UKZN residences are occupied by almost 99.9 per cent Black African students, with only the occasional international White student. The predominantly Black residences appear to be microcosmic replicas echoing the views of the women's home spaces. All of this was mirrored by Lufuno who said,

I didn't want to be 'the lesbian', and I was scared and felt it wasn't normal and I didn't want to be this person who would be discriminated against. Society as whole discriminates us as abnormal and it's no different on campus .... (Lufuno).

D’Augelli and Rose (1990) in their early survey studies of first year students on a university campus, state that 29 per cent of heterosexual students believed that their institution would be better in the absence of gays and lesbians. Diaz et al (2001) articulate that the unfavorable judgement that comes with sexual orientation, deemed deviant by the majority, have immense impact on most lesbian women, making it difficult for them to come to terms with their identity. From some of the experiences shared by the women at UKZN, most of the discrimination towards lesbian students emanates from the male students, although they felt that they were judged (as deviant) by both male and female students.

\section{Theme: The epistemic violence of words}

Doris had shared, '... [P]eople ... Us[e] "those” words on me'.

Doris, when pressed, mentioned 'those words' as terms such as 'stabane' and 'brothersister'.

It was Harcourt and Escobar $(2002,7)$ who pointed out the poignant reality that the 'line separating the corporeal body and the social body is flimsy' and what exists is instead the 'social flesh'. Doris' utterance of 'those' words highlighted the immense epistemic violence that appears to be encoded within words and verbal exchanges. Doris’ painful sharing appears borne out by research which also reveals that often lesbian and gay students encounter verbal harassment (see Schope and Eliason 2000; Burn 2000; Rankin 2003). Pejorative words such as, 'fag', 'dyke', 'lesbo' and 'queer', are often routinely used as lesbian insults in verbal assaults.

In the South African context, denigrating words such as, 'moffie', 'stabane', 'buti', 'brother sister' or 'double adaptor', are used to violently mock those who are identified as lesbian (see Mavhandu-Mudzusi and Netshandama 2013, 716). From the narratives shared, it became clear that such words are viscerally experienced by the students.

Sometimes the violence and erasure in the grammar and import of words becomes inverted and self appended, with the women using words that show they have been compelled to accept 
and self ascribe certain heteronormative sexual constructions. Consider the words of Khuliso,

It gets even more tricky when you are a lesbian woman and even trickier when you are a masculine (sic) woman [she looks down at herself and points to her physique and her pants and shirt ensemble]. You see the reason why I feel this way is the fear of being corrected into straightness, the physical and sexual abuse we suffer by our fellow African brothers on campus because we are, 'taking their girlfriends'. They want to show us that we are women and we need a real thing! It is scary. (Khuliso).

In Khuliso's narrative and her choice of words such as 'masculine', there is an inherent conflation of a non-normative gender expression (in terms of dressing 'butch') and sexual orientation (in terms of having a relationship that is romantic and/or sexual). Khuliso is in a sense identifying two critical but different aspects. Her narrative reminds us that gender expression and non-conformity lends itself to various levels of direct (and indirect) discrimination and reactions (regardless of the individual's sexual orientation) by a heteronormative society.

Her narrative also brings together the themes of 'being lesbian and different/deviant' and the 'violent verbal harassment' and fear simmering in the utterance, 'taking their girlfriends'.

Khuliso's choice of words also reveals that for her, there is no ambiguity around her use of the word 'thing'. Her conjoining of the use and meaning of 'real' and 'thing' underpins the entanglement of social body and physical body in both discourse and everyday practice. This narrative poignantly underscores the imbrications of the intersectional reality for Khuliso, who has adopted the vernacular of the oppressor, by voicing her fear for her 'self' and 'body' when she says that as a Black woman, she fears 'being corrected into straightness'. Xoliswa's words, spoken privately, appeared to mirror and echo that of Khuliso,

You see the thing is being a woman I don't feel safe at all. It's even worse when people know that you are lesbian, and an African woman ... we are meant to be straight according to them you know ... and then now you see you are prone to corrective rape, you know.

Xoliswa also said, 'I didn't want to be the lesbian'. Here the very word 'lesbian' is made to be experienced as a 'dirty' word in both signification and semiosis. Evocative of the Stalinist rule of Napoleon, the Ruling Pig on George Orwell's’ Animal Farm, there are clear hierarchies and demarcations of those deemed worthy and those sentenced as unworthy. As in the writing on the barn wall in the case of the Napoleon's commandments; some are more equal than others.

The above two narratives reveal how themes 'leech' one into another and intersect and overlap in an experiential way. Xoliswa self references being lesbian as being 'different'. She also simultaneously self references being a Black African woman and lesbian.

While issues of bodily safety and bodily harm are a critical vector of concern for all female 
students, as Khuliso mentions, safety takes on a double significance and is amplified if you are identified as lesbian. This is moreover heightened if you are a Black African lesbian and perceived as deviant and different and also culturally branded as 'sexually different' and nonnormative.

The term 'intersectionality’ is deployed in the literature and operationalised in various studies in the context of either a theory or method, or both, and is used to identify and study the ““real world” phenomena of structural, political, and representational intersectionality’ (see Carastathis, 2014, 307). In the context of the narratives in the study, the intersectionality of race and gender is entangled 'one into the other' and is further tightly braided with theologically laced words and understandings of religion which further cements the idea that homosexuality and lesbianism is both a Western import foisted on African people and especially African women. While this normativity is often constructed in terms of the naturalised understandings of male and female, often the naturalised heteronormative order is propped up by the scaffold of religion (see Naidu 2013), where the neat binaried male and female coupling is seen as divinely ordained.

Campus life appears not immune from this and thus often vitriolic homophobic tendencies and verbal harassments are also orchestrated from different (fundamentalist) religious perceptions that students have on campus. Studies by Arndt and De Bruin (2006) reveal that much of the resentment on the campuses comes from Christian students who are tenacious about upholding their (constructed understandings of their) religion, and who identify homosexuality as a fundamental sin. This is certainly echoed in the first year Anthropology classes in which one of the authors taught, where the most vociferous resistance to the curricular content of sexual diversity appeared to come from religious students. Many of the (anonymous) module evaluations housed comments that the lecturer should 'stop teaching about gays and lesbians' and that they 'did not wish to learn about that filth'. One of the participants shared that these words were often violently hurled at her,

God never made Eve and Eve. He made Adam and Eve, asikho isdingo sokuzenza indoda ungeyonaso.

She also shared that comments asking, 'why are you trying to act like a man when you aren't one', often bordered on the aggressive and violent.

Although the above observations refer to Christian students, religious conservatism of course is wider (Christian, Muslim, Hindu etc.) This kind of conservatism lends itself to oppressive, often strongly patriarchal, heteronormative constructions, and is said to be divinely prescribed. 
Belue $(2015,2)$ purports that religion plays a pivotal role in brewing up a rife ideological environment against homosexuality and in turn perpetuating discrimination; verbal and sometimes even physical. Graham and Kiguwa $(2005,8)$ concur with Belue and state that religion (and the religious hermeneutic) is deployed to (epistemologically) discredit the status of those who self-identify as lesbian or gay, and terms it as a sin. Being heterosexual is perceived to be normal and divinely sanctioned and this emanates from the theological understanding that God created two complementary sexes (Gerber 2008, 13). Naidu $(2013,5)$ asserts that often attending a religious congregation leads to a silencing of ones sexuality just so one can 'fit in' and avoid being (seen as) 'abnormal' and being called unclean. Regarding the potential violence of religious epistemes on campus, one of the students had this to say,

I hate it a lot when I am walking around campus and I see a poster saying, 'no to homosexuality'. I feel like some people treat us like we are not human and it really is worse when you are a Black woman. Imagine I had to attend one of the church groups on campus and they start preaching about homosexuality as a sin. It is as if being lesbian is a huge sin and I am not normal ...

I hate it when students use the bible as ammunition, they forget that religion is a choice, always I hear that what you are doing is so unchristian they tell me about Sodom and Gomorrah, like really?! .... (Nomzamo).

The lesbian students' narratives indicated a deep fear that the aggressive remarks (verbalized or in print) from religious fundamental students could easily turn into violence and (corrective) rape. They also echoed that they felt that the university was responsible for ensuring that such 'hate posters' not be displayed. Yet they felt unsure as whom to complain to and believed that it was not their responsibility to 'police' the display boards but that of the university authorities.

The Human Rights Watch report $(2011,26)$ states that verbal abuse and harassment 'communicates' to lesbian women that they are loathed, stating what must seem palpably obvious in such instances; that verbal abuse creates a negative self-image inhibiting their ability to 'come out' with their sexual orientation. Certainly Xoliswa's story bears this out. Graziano’s (2004, 280) study also offer insights around homosexual students' fearing 'coming out' at universities because of the levels of verbal (and physical) victimization that occur around campuses.

Dworkin $(2000,165)$ argues that for most lesbian women, the university years are when they undergo an 'identity transformation'. One does not take this to mean that the women unexpectedly experience a transformation or radical change in their sexual identity or orientation, but rather that this period offers a transitional and self-reflective period to engage with and grapple with issues of sexual identity. According to Dworkin, the women go through a process that involves 'shifting' $(2000,165)$ ones identity to (what is perceived by the wider 
community as) the socially degraded non-heterosexual lesbian identity. This understandably renders the university experience fraught and beset with potentially oppressive challenges. Arndt and De Bruin $(2006,19)$ state that the 'coming out' process is never easy because lesbian students have to face criticism for their sexuality choices.

\section{Theme: Supportive kinship networks}

The fact that at some point in time I had to live under the shadows was a great challenge. I could not even find anyone whom I related to or someone who was also lesbian. I think that was so, because nobody really says it out aloud that 'I am lesbian'. You will only get to know after a while. In my case I only started associating with people same as me when I attended an LGBTI church service in town. That's how I connected with some lesbians and was even surprised to meet some familiar faces from campus there. Then we connected on campus ... some of us through the LGBTI Forum on campus. (Jabu).

Jabu claimed that one of the challenges she faced being a student at the UKZN was not being able to just let everyone know that she was interested in people of the same sex. She says she relied solely on her small circle of friends.

In a focus group, Rose, Sli and Doris unanimously noted that being part of the LGBTI group on campus made the campus environment relatively more welcoming for them.

My circles have always been comprised of other lesbians, so I don't really feel unwelcome when I am around campus. I feel that the group that we have is a great support system, at least we get to socialize and know other people whom we identify with. (Rose).

Yah it totally makes one aware that everything is okay ... we are just normal people and well what I like about the group is we get to develop strong and honest friendships actually knowing that no one is judging you. (Sli).

Honestly I don't know what I would do without this group because they are the ones who just make my stay here at UKZN easier and welcoming. (Doris).

The narratives above render explicit that the lesbian students felt accommodated through their strong nodal ties in their cliques and groups and nodal networks such as the LGBTI Forum, rather than by the university itself.

Like other kinds of minority groups, the relationships and ties fostered within these networks, offers security and a kind of built in kinship pool of reciprocal relationships (see; Naidu 2010; Naidu 2012). The narratives above also strongly echo Hagen (2012, 4) who states that lesbian student organisations play a fundamental role for most students, creating a social platform and support system where students interact and construct lifetime friendships.

When asked as to whom the lesbian students felt were responsible for their welfare, safety and general student life; the students interviewed both individually and in focus groups echoed 
each other,

Well it is supposed to be University, first they should draw up some sort of policy, I don't really know what policy, but some policy which goes hand in hand with the LGBTI group to ensure that there are more awareness groups, more inclusion, I don't know many lesbians on campus. We at least should be able to know one another .... The group should improve ... like if you go to Mangosuthu University, you know they are an active group. They call it 'Alive', I think. And you know ... that's a very active group. Yah at UKZN it's there ... but it feels like it's not the issue of the moment, it's so low. (Xoliswa).

It is definitely the responsibility of the University to make sure that LGBTI issues are sorted out. Yes there might be the group [referring to the LGBTI Forum] that's there for us but I do feel that that's the only effort that it put and that was it. It's more like doing it for the sake of saying oh yes we do acknowledge LGBTI's and then that's the end of it, but it is our right to be who we are. (Sli).

The statement from Sli is insightful in as much as it is frustrating. It offers phenomenological and palpable experiential context that transformation at UKZN stops short of fully addressing or satisfying pressing concerns of full inclusivity and campus citizenship. Changes to recognise sexuality difference appear more ameliorative than transformative. Sli's assertion and attempt at reclaiming her sexual right as her human right in the words, 'but it is our right to be who we are', is poignant.

\section{DISCUSSION: LESBIAN RIGHTS AS HUMAN RIGHTS AND THE HIGHER EDUCATION TERRAIN}

'Sexual orientation' as a right not to be discriminated against is clearly present in the South African Constitution. According to Article 9(3) (The Constitution of the Republic of South Africa 1996):

The State may not unfairly discriminate directly or indirectly against anyone on one or more grounds, including race, gender, sex, pregnancy, marital status, ethnic or social origin, colour, sexual orientation, age, disability, religion, conscience, belief, culture, language and birth.

However, the exegetical import of legislature or legal doctrine suffers gross oversimplification in translation. Quite simply, to continue the scriptural metaphor, 'gospel' does not fully reach praxis. This is no less evident within a post-apartheid higher education context. There is however, much situated research needed to draw critical attention to this.

While there has been some important work done internationally and within South Africa with people who identify as lesbian, bisexual or gay, there has been relatively less work done within a higher education context. Earlier research (such as Longerbeam et al. 2007 study) around lesbian university students also focused on overt and covert discrimination towards 
lesbian students but looked at the views of heterosexual students towards lesbian lifestyles. Moreover, not all of the work has been empirically grounded or focused on qualitative analyses of the experiences of lesbian, bisexual or gay students, and still fewer studies have focused more specifically on lesbian women and their narratives of experiences within higher education institutions, which has been the aim and the point of insertion of this study.

As the findings revealed, the exigency of full sexual citizenship and legitimate inclusive campus citizenship for lesbian students cannot be reductively separated from the structural intersectionalities within which they find themselves, in this instance as African students. And in the absence of perceived support and recognition from the university authorities, the women who self-identify as lesbian turn to nodal networks and ties forged within cliques and networks (such as the LGBTI Forum), which in turn comprise other Black African lesbian women.

In the context of the lesbian students at UKZN, the argument is that the entanglement of the structural and intersectional strands oblige a particular 'performance' (see Butler 1988; Butler 1990) of 'self' (see Goffman 1959) within the physical and ideological institutional spaces of the University. Notwithstanding the transformation jargon adopted and various policies of equity implemented, the women's performance of 'self' is experienced as contriving to rob and swindle the students of their full sexual citizenship, and render them at best, second class citizens, and at worst, 'classless' or non-existent as the invisible other within their higher education institute.

In their own ways and through their narratives, this was what the women were attempting to share in and through their storied experiences. Through their pain around being made to feel as deviant and abnormal and being made to experience the violence of verbal discrimination, the women communicate their profound disappointment and frustration at having higher education policies and their university abysmally failing and neglecting them and their alternate sexual identities.

This neglect, one suggests, is blanketed and cloaked by higher education policy's earnest, yet myopic quantitative attention to numerical strength, in turn validated by numbers. Thus, in terms of policy translation, the rhetoric of 'campus citizenship for all' in terms of an 'access' policy, equates primarily to increasing access and opportunity for racial groups and genders that had been previously denied entry to higher education. This increase in access to higher education was (and is) nevertheless still within a dominant heteronormative context. In terms of engendering policy, this meant then actively seeking to increase the numerical presence of women, especially Black African women (and then increasing the presence of young Black African entrée level staff within the wider academy). All of this is however, enacted in the 
absence of a nuanced and contextual understanding of gender and gender regimes and sexual rights.

Thus, although the South African government has shown a level of public commitment to acknowledging and upholding diverse sexual orientation and indeed LGBTI rights, negative attitudes and behaviour towards LGBTI persons are prevalent and entrenched in many spaces - including university communities (see Arndt and De Bruin 2006, 16).

Probing such positioning, Hames' paper is significant in as much as it sought to candidly interrogate the 'dominant rhetoric of "sexual citizenship for all” in the post-apartheid South Africa'. She attempts this through a critique of government's role in drawing up the agenda/s for higher education policy design and implementation (2007, 52). Rather aptly titled 'Sexual Identity and Transformation at a South African University', her paper reminds us that policies, even when seemingly well intentioned, are never neutral, they are in reality, political and 'disciplining' texts (Foucault 1977). Hames drew critical attention to the rather, 'essentialist' (2007, 52) and binaried understanding of [a]'gender' in policy frameworks in higher education, that fail to take cognizance of sexual orientation or sexual identities. She goes on to trenchantly state,

[W] hat can be said about the implicit values of these policies, about their covert biases and their neglect of homosexuals' [and lesbians'] substantive rights and needs in higher education institutions? (Hames 2007, 52).

Rankin $(2003,3)$ further argues that though universities provide a variety of opportunities and certain measurable safety mechanisms (controlling access points etc) for its students, these are greatly inadequate and do not necessarily offer security to gay and lesbian students on the campuses. As the narratives show, the lesbian students still fear for their safety on campus and are deeply hurt by harassing and aggressively violent remarks. None of this feature on UKZN's adopted tagline; 'Be Inspired!'

Instead UKZN brands itself around the notions of 'premier' and 'African' and employs compelling transformation jargon. Couched within this seemingly transformative stance has been the recent 2015 launch of a LGBTI Forum and a Forum Leader employed.

The LGBTI Forum has held some very successful dialogues and conversations with progressive student leaders from student leadership and student faith groups also attending. However, by and large, these dialogues appear insulated and a case of 'conversing with the converted'. While the LGBTI Forum has a vital role to play, it appears that the university executive authorities do little to leverage such events to showcase and draw in the wider university community of staff and students. A case in point is that although both the HIV/AIDS 
Programme and the LGBTI Forum functions under the umbrella of Student Health at UKZN, the former receives wide coverage and draws the attendance of executive leadership while the latter (LGBTI) Dialogue/s draws in mainly the female Health Programme coordinator. At UKZN, the LGBTI Forum existing under the wing of The Student Health and HIV Programme which funds and also oversees the events and activities of the Forum compounds how it may be viewed by the non-homosexual community of students. In an interview with counselling staff involved with student services, the respondent who was a senior staff member voiced that she felt that this perpetuated stigmatisation of students with different sexual orientation.

All of this lends credence to the participants' assertions that the university felt it had done its job 'just because the Forum had been created for them'. Thus it would appear that a potentially powerful space and opportunity to engage with the realities that lesbian and gay students at UKZN faced, was being squandered by the University authorities.

Thus, understandably, the qualitative narratives and empirical lived experiences of the women in this study largely reveal that 'transformation' had not extended to sexual citizenship. This equates to a denial of the fundamental sexual and human rights of these students.

Like Rankin (2003), Collier $(2001,11)$ pointed out that most universities at the turn of the century were 'cautious' when it came to extending equal rights and social justice to members of the gay and lesbian community. Universities are also noted as being like the proverbial tortoise, and slow to change. However, one contends, unlike the tortoise in the children's fable whose slow and steady pace ultimately wins the race, change in this context is 'slow and not even steady'. Thus, discrimination against lesbian students remains rife as the findings reveal. The University of KwaZulu-Natal's robust (and laudable) transformation stance (in policy and praxis) which focuses on decolonising epistemologies and pedagogies, appears to have overlooked the recognition of sexual citizenship for all students. We are back on George Orwell's Stalinist Animal Farm; all (rights) are equal, but some (rights) are more equal than others.

\section{CONCLUSION}

The narratives of students who self-identify as lesbian at the University of KwaZulu-Natal revealed that their experiences are fraught, oppressive and complex. While it was not the initial aim of this study to sample solely Black African lesbian women at UKZN, the final sample community emerged as Black African women. This obliged a grounded and contextually situated approach and in turn permitted and authorised a recognition of the experiences that were unique to Black lesbian women's lives in a South African context, which is in many ways 
replicated at an institute like UKZN. This is highlighted by the fact that Black African women constitute more than 50 per cent of the student population at UKZN and that Black African students (male and female) constitute the majority of the student body at this university. The university is also home to several strong student religious organisations with many of the Christian student bodies dominated by Black African students. All of this allowed a particular grounded approach and intersectional lens to be adopted in both data collection as well as data analyses.

In a wonderfully philosophical piece on the epistemological roots of intersectionality as a method and theory, Anna Carastathis (2014, 308) claims that a necessary corollary of the complexity embedded in the paradigm of intersectionality 'is the irreducibility benefit'. For Carastathis, what this means is that we avoid reading oppression as ascribed to any one singular foundational category. For Carastathis this would be 'ontologically privileging that category, [yet] intersectionality theorists argue that oppression is produced through the interaction of multiple, decentered, and co-constitutive axes' $(2014,308)$. The point is that multiple oppressions such as gender and race are not merely assistive and additive but exist densely and complexly, simultaneously and inclusively. They are thus not reducible. This is certainly true for the women on campus of UKZN, whose narratives and experiences speak to the imbrications of both gender and racial, as well as cultural and religious oppressive (and normalised) regimes that all braid together intersectionally, and stand in irreducible relationship to each other.

The phenomenological experiences captured in the narratives of the study reveal that the students feel that their fundamental human rights in the context of sexual citizenship is largely denied to them or not facilitated within the institutional spaces of the university.

Scholars and activists working with the lesbian and gay are clear that, given the legislature on the rights of alternate sexual orientation in South Africa; it is the responsibility of organisations and institutions to ensure that sexual minority rights are accommodated. It follows that universities and other educational institutions are also part of a community that are morally obliged to ensure that lesbian, gay, and indeed wider LGBTIQ rights are adhered to as part of the wider suite of fundamental rights for students on campus.

Collier states however, that university administrators often non-reflexively rubber stamp matters regarding LGBTI rights on campus. Thus, in their studies Mavhandu-Mudzusi and Netshandama (2013) and Abaver et al. (2014), recommended that universities should become more receptive and reflexive and improve their awareness to address issues of stigma and discrimination on campuses, and point to what should be quite obvious, but is yet to be put in 
place; the need for universities to include LGBTI issues and tenets in curriculum development and curriculum design. This takes on heightened significance in a University such as UKZN which brands itself as the 'Premier African University' and congratulates itself on African Scholarship and transformation.

At UKZN, there is concerted and sustained effort and 'policy revisiting' in attempts to decolonise what is construed as imperialist epistemologies and pedagogies embedded with the earlier colonial curricula. There are also, efforts to increase the number of Black African students and staff and increase the number of Black Africans, especially Black African women at the higher levels of management and the academy. However, these critical exercises stop short of satisfying critical issues of full inclusivity and campus citizenship. Changes to recognise sexuality difference and sexual orientation appear more ameliorative than transformative. Thus, the transformation appears to stop short of addressing the inclusion of full sexual citizenship for students who self-identify as lesbian and gay.

As the voices and narratives in this study reveal, the notion of campus citizenship as accepted by most universities, including UKZN, appears to covertly elide, that is to say, ignore or erase sexual citizenship as one of the fundamental human rights for students within university spaces.

\section{REFERENCES}

Abaver, D. T., E. N. Cishe, N. Twaise and D. T. Goon. 2014. Knowledge, perception and behaviour of students towards the lesbian, gay, bisexual, transgender and intersex (LGBTI) community at Walter Sisulu University, Eastern Cape, South Africa. African Journal for Physical, Health Education, Recreation and Dance 20(4): 1353-1364.

Arndt, M. and G. de Bruin. 2006. Attitudes toward lesbians and gay men: Relations with gender, race and religion among university students. PINS 33: 16-30.

Belue, J. 2015. Free to be: Supporting lesbian, gay, and bisexual students on Catholic campuses. The Vermont Connection 27(3): 1-7.

Bertram, C. and I. Christiansen. 2014. Understanding research: An introduction to reading research. Pretoria: Van Schaick.

Burn, S. 2000. Heterosexuals' use of 'fag' and 'queer' to deride one another: A contributor to heterosexism and stigma. Journal of Homosexuality 40(2): 1-11.

Butler, J. 1988. Performative acts and gender constitution: An essay in Phenomenology and Feminist Theory. Theatre Journal 40(4): 519-531.

Butler, J. 1990. Gender trouble: Feminism and the subversion of identity. New York: Routledge.

Carastathis, A. 2014. The concept of intersectionality in Feminist Theory. Philosophy Compass 9(5): 304-314.

Collier, H. W. 2001. Gay men and lesbians in the university community. Faculty of Commerce Papers (Archive). http://ro.uow.edu.au/cgi/viewcontent.cgi?article=1033\&context=commpapers (accessed 2 February 2016).

D'Augelli, A. R. and M. L. Rose. 1990. Homophobia in a university community: Attitudes and experiences of heterosexual freshmen. Journal of College Student Development 31: 484-491. 
Diaz, R., G. Ayala, E. Bein, J. Henne and B. V. Marin. 2001. The impact of homophobia, poverty and racism on the mental health of Latinogay and bisexual men: Findings from three U.S. Cities. American Journal of Public Health 91: 927-932.

Dworkin, S. H. 2000. Individual therapy with lesbian, gay, and bisexual clients. In Handbook of counselling psychotherapy with lesbian, gay and bisexual clients, ed. R. M. Perez, K. A. DeBord and K. J. Bieschke. Washington, DC: American Psychological Association.

Forsythe, D. P. 2009. Human rights in international relations. 2nd Edition. United States of America: Cambridge University.

Foucault, M. 1977. Discipline and punish. London: Allen Lane.

Gerber, L. 2008. The opposite of gay: Nature, creation, and queerish ex-gay experiments. Nova Religio: The Journal of Alternative and Emergent Religions 11(8): 9-12.

Goffman, E. 1959. The presentation of self in everyday life. Garden City, NY: Doubleday Anchor.

Graham, T. and S. Kiguwa. 2005. Experiences of black LGBT youth in peri-urban communities in South Africa. Cape Town. Institute for Democracy in South Africa (IDASA) 15: 1-27.

Hagen, J. 2012. Global security equals human security and gender rights. http://www. ontheissuesmagazine.com/2012fall/2012fall_Hagen.php (accessed March 2015).

Hames, Mary. 2007. 'Reclaiming the P... Word': A reflection on an original feminist drama production at the University of the Western Cape. Feminist Journal Africa 9: 93-101.

Harcourt, W. and A. Escobar. 2002. Women and the politics of place. Development 45(1): 7-14.

Harrison, L. 2001. Political research: An introduction. New York, Routledge Publishers.

Herek, G. M. and K. T. Beril. 1992. Hate crimes: Confronting Violence against lesbians and gay men. Newsbury Park, CA, Sage.

Graziano, KJ. 2004. Coming out on a South African university campus: Adaptations of gay men and lesbians. Society in Transition 35(2): 273-286.

Langdridge, D. 2007. Phenomenological psychology: Theory, research and methods. London: Pearson.

Longerbeam, S., D. R. Johnson, K. K. Inkelas, Z. S. Lee. 2007. Lesbian, gay, bisexual college student experiences: An exploratory study. Scholarly Journals 48(2): 215-232.

Mavhandu-Mudzusi, A. N. H. and V. O. Netshandama. 2013. The attitudes of students towards the lesbian, gay, bisexual, transgender and intersex community: A case of a South African, rural-based university. African Journal for Physical, Health Education, Recreation and Dance supplement 1(1): 56-66.

Mohipp, C. and M. M. Morry. 2004.The relationship of symbolic belief and prior contact to heterosexual attitudes towards gay men and lesbian women. Canadian Journal of Behavioral Science 36: 3650 .

Naidu, M. 2010. Tied to each other: Gazing on religion and networked connectivity and closuretransnationalised work and workers. In Anthropology today: Contemporary trends in social and cultural Anthropology, ed. Shalini Mehta, 13-24. Delhi India: Kamala Raj Enterprises.

Naidu, M. 2012. 'Mind the gap': The structural ecology of small networked communities. Alternation 19(1): 280-305.

Naidu, M. and K. Ngqila. 2013. 'Enacting masculinities: Pleasure to men violence to women'. Agenda. http://dx.doi.org/10.1080/10130950.2013.793898 1-10 (accessed 15 October 2015).

Naidu, M. 2013. Sinful (!) liaisons: Being lesbian and religious. Journal of Gender and Religion in Africa 19(1): 1-18.

Nath, D. and Human Rights Watch Org. 2011. We'll show you you're a woman - Violence and discrimination against black lesbians and transgender men. South Africa: Human Rights Watch Press. (accessed online 5 February 2015).

Office of the High Commissioner for Human Rights. 1996. http://www.ohchr.org/EN/issues/pages/what are human rights.aspx (accessed 13 May 2015.) 
OHCHR see Office of the High Commissioner for Human Rights.

Peters, J. P. 2003. Isolation or inclusion: Creating safe spaces for Lesbian and gay youth. Families in Society 84: 331-340

Rankin, S. R. 2003. Campus climate for gay, lesbian, bisexual and transgender people: A National perspective. New York: The National gay and lesbian task force policy institute.

Schope, R. and M. Eliason. 2000. Thinking versus acting: Assessing the relationship between heterosexual attitudes and behaviors toward homosexuals. Journal of Gay and Lesbian Social Services 11(4): 69-92.

Swank, E. and L. Raiz. 2010. Attitudes toward gays and lesbian among undergraduate social work students in affiliate. Journal of Women and Social Work 25(1): 19-29.

The Constitution of the Republic of South Africa. 1996. http://www.justice.gov.za/legislation/ constitution/SAConstitution-web-eng.pdf (accessed 5 February 2015).

Thiel, M. 2014. LGBT politics, queer theory and international relations. www.e-ir.info/2014/ 10/31/lgbt-politics-queer -theory-and-international -relations (accessed 15 August 2015).

Tiripano, T. 2000. Fighting for lesbian and gay rights in Zimbabwe. off our backs 30(4): 1-11. 